\title{
REFLEKSI SEJARAH DAN SOSIAL POLITIK DALAM NOVEL PARA PRIYAYI KARYA UMAR KAYAM
}

\author{
Agus Yulianto \\ Balai Bahasa Provinsi Kalimantan Selatan \\ Pos-el: agusb.indo@gmail.com
}

\begin{abstract}
Abstrak
Tujuan penelitian ini adalah untuk menjelaskan unsur-unsur kesejarahan dan realitas sosial politik yang terdapat dalam novel Para Priyayi karya Umar Kayam. Adapun masalah dalam penelitian ini adalah seperti apakah unsur-unsur sejarah dan realitas sosial politik yang terdapat dalam novel Para Priyayi yang dijadikan sebagai objek kajian. Metode yang digunakan dalam menganalisis novel adalah metode deskriptif kualitatif dengan menggunakan pendekatan sosiologi sastra. Berdasarkan hasil analisis dapat diketahui bahwa novel Para Priyayi banyak sekali merefleksikan unsur-unsur kesejarahan baik di zaman Belanda, Jepang, Indonesia merdeka, zaman revolusi sampai pada pemberontakan G-30-S PKI. Demikian juga realitas sosial politik yang terdapat dalam novel merupakan sebuah refleksi yang pernah terjadi Indonesia.
\end{abstract}

Kata kunci: sejarah, novel, sosial politik

\begin{abstract}
The purpose of this study is to find out the elements of historical and social-political reality in the novel Para Priyayi by Umar Kayam. The problem of this research is how the elements of history and social-political reality found in the novel Para Priyayi look like which serve as the object of this study. The methodology used in analyzing the novel is descriptive qualitative method by using sociology of literature approach. Based on the analysis from The Priyayi Novel, there are a lot of historical elements in Netherland periode, Jepang, Indonesian freedom, revolution periode, until rebellion of G-30-S PKI. Alsososial politics reality that appear in the novel is a reflection tht exist in Indonesia country.
\end{abstract}

Key words: History, novel, social politics

\section{PENDAHULUAN}

Menurut Khakim (2016:15) sejarah pernah menjadi bagian dari sastra. Sampai saat ini sejarah juga dekat dengan sastra, terutama dalam hal penggunaan sumber naskah tertulis. Sejarah kini sudah masuk dikenal masyarakat ke dalam berbagai bentuk. Sejarah pada umumnya ditulis dalam bentuk buku ilmiah yang sulit dipahami. Seiring dengan perkembangan teknologi, sejarah juga diungkap dalam bentuk buku menjadi bentuk bacaan lain seperti karya sastra sejarah, baik berupa puisi, cerpen, dan novel.
Lebih jauh Khakim (2016:15) menyatakan hal yang menarik dari penerbitan dan peredaran karya sastra berbau sejarah adalah karya sastra ini justru lebih banyak diminati dibandingkan buku sejarah pada umumnya. Masyarakat berbondong-bondong membeli karya sastra sejarah berupa novel dan kumpulan cerpen di toko buku. Novel berlatar sejarah terjual yang laris dan memiliki animo tinggi dari masyarakat bahkan diangkat ke layar lebar seperti novel Tenggelamnya Kapal van Der Wijck. Menurut Ali (2005:35) karya sastra berlatar sejarah perlu disusun berdasarkan 
kaidah penulisan sejarah. Karya sastra sejarah tidak boleh ditulis hanya bersumber pada imajinasi penulis. Karya sastra sejarah dalam bentuk cerita tidak dapat dipisahkan dari penyusunannya, meskipun penyusun harus berdasarkan fakta sejarah. Cerita itu tidak akan dapat disebut cerita sejarah jika penyusun utama dikuasai oleh pribadi sendiri saja dan mengabaikan fakta-fakta sejarah. Karya sastra sejarah harus ditulis dengan penelitian lebih dahulu menggunakan sumber-sumber sejarah yang relevan.

Selanjutnya, Ali (2005:35) juga menyatakan suatu kejadian peristiwa yang bersifat kemanusiaan dapat dipilih dan ditentukan menjadi isi cerita sejarah apabila kejadian atau peristiwa itu menggambarkan perjuangan manusia ke arah kehidupan yang lebih sempurna; selain itu, juga jika kejadian peristiwa, riwayat hidup seseorang manusia itu merupakan bagian penting dari perjuangan suatu negara, kota, daerah, desa, atau lingkungan kehidupan kenegaraan.

Salah satu novel yang berlatarbelakang sejarah yang ada di Indonesia adalah novel yang berjudul Para Priyayi karya Umar Kayam. Novel ini mengisahkan tentang perjuangan seorang wong cilik dalam meningkatkan status hidupnya menjadi seorang priyayi serta seluruh dinamika kehidupannya sebagai seorang priyayi baru.

Priyayi adalah sebutan untuk para bangsawan yang ada di Pulau Jawa, khususnya Jawa Tengah dan Jawa Timur saat ini. Eksistensi priyayi sudah ada sejak zaman kerajaan-kerajaan di tanah Jawa sampai di zaman penjajahan Belanda, penjajahan Jepang bahkan sampai saat ini seperti yang ada di kesultanan Yogyakarta dan Kasunanan Surakarta.

Novel Para Priyayi ini sangat kaya dengan informasi-informasi kesejarahan dan realitas sosial politik mengenai eksistensi priyayi beserta dinamika kehidupanannya. Hal itu disebabkan masa penceritaan novel ini berlatarbelakang sejarah permulaan abad ke-20, yaitu saat pergerakan politik mulai tumbuh di kalangan priyayi. Selain itu, masa penceritaan yang meliputi zaman Belanda, Jepang, Indonesia merdeka, zaman revolusi sampai pemberontakan G-30-S PKI membuat novel ini sarat dengan informasi kesejarahan. Di sisi yang lain, kehidupan sosial politik yang melingkupi Indonesia pada saat itu serta serta yang menimpa para priyayi khususnya yang terdapat dalam cerita memberikan gambaran yang cukup jelas tentang keterlibatan para priyayi dalam dinamika sosial politik pada saat itu. Oleh sebab itu, pendekatan sosiologi sastra dapat digunakan untuk menganalisis dinamika sosial politik dalam cerita sebagai sebuah pendekatan yang cukup relevan untuk memahami latar sosiologis dalam cerita.

Menurut Junus (1984:57) bertolak dari konsep sastra adalah cermin masyarakat atau cermin suatu zaman atau sastra adalah refleksi sosial atau refraksi sosial atau juga sastra merefleksikan kehidupan, maka suatu karya sastra akan mengandung unsur sosial yang penting dari realitas sosial yang dilukiskannya. Dengan kata lain sebuah unsur penting dalam realitas sosial terlihat dalam karya sastra yang melukiskan realitas itu. Paling tidak, karya itu akan menolak unsur yang berasal dari rrealitas lain. Demikian juga novel Para Priyayi, relitas sejarah dan realitas sosial politik yang terdapat didalamnya menjadikan novel ini menarik untuk dianalisis dengan menggunakan pendekatan sosiologi sastra.

Dengan demikian, tujuan penelitian ini adalah untuk mengetahui unsur-unsur kesejarahan dan realitas sosial politik yang terdapat dalam novel Para Priyayi karya Umar Kayam. Adapun masalah dalam penelitian ini adalah seperti apakah unsur-unsur sejarah dan realitas sosial politik yang terdapat dalam novel Para Priyayi yang dijadikan sebagai objek kajian.

\section{TEORI DAN METODE}

Menurut Roesmiati (2016:33) hubungan sastra dan sejarah dapat dikelompokkan men- 
jadi tiga kategori. 1) Karya sastra yang merekonstruksi sejarah berdasarkan sumbersumber yang terpercaya dan bisa dipertanggungjawabkan. Di sini, sastra sejarah mencapai titik temu, yaitu keduanya adalah naratif baik tokoh maupun latarnya. Meskipun karya sastra pada dasarnya subjektif, novel sejarah dalam kategori ini sedikit banyak bertendensi objektif dalam arti sejauh mungkin berdasarkan fakta; 2) karya sastra yang merekam sekaligus menanggapi suatu peristiwa sejarah. Dalam batas tertentu, karya sastra tersebut merupakan bagian dari peristiwa sejarah itu sendiri, misalnya kumpulan puisi Tirani dan Benteng karya Taufik Ismail yang merekam demonstrasi mahasiswa tahun 1966 yang menentang Soekarno; dan 3) Karya sastra yang menafsirkan dan atau mempertanyakan sejarah (masa lalu) demi melihat relevansinya dengan masa kini dan masa depan. Bisa juga menyuarakan aspek-aspek sejarah yang - sengaja atau tidak sejauh ini tidak disuarakan. Karya sastra kategori ini menekankan moral sejarah sebagai pilihan aktual.

Menurut Teeuw (2003:247), kenyataan yang ditulis pengarang merupakan kenyataan yang terjadi pada masa lampau, masa kini, dan masa yang akan datang. Pemakaian realita masa lampau atau sejarah dalam sastra dapat melahirkan karya sastra sejarah. Tempat kejadian, tokoh, peristiwa dalam sejarah dipakai sastrawan menulis karyanya. Dari fakta itu, lahir karya fiksi. Menurut Kuntowijoyo (2008: 27), pemakaian fakta dalam sastra memiliki tujuan, yaitu :

1. Mencoba menerjemahkan peristiwa sejarah dalam bahasa imajiner dengan maksud untuk memahami peristiwa sejarah menurut kadar kemampuan pengarang.

2. Karya sastra dapat menjadi sarana bagi pengarangnya untuk menyampaikan pikiran, perasaan dan tanggapan mengenai suatu peristiwa sejarah.

3. Seperti juga karya sejarah, karya sastra dapat merupakan penciptaan kembali sebuah peristiwa sesuai dengan pengetahuan dan daya imajinasi pengarang.

Menurut Mahayana (2005:361), menjelaskan, jika karya sastra itu lebih banyak mengangkat fakta sejarah, tidak sedikit pula masyarakat yang memperlakukannya sebagai karya sejarah. Oleh karena itulah, dalam beberapa hal, hakikat sastra sering dianggap tidak jauh berbeda dengan hakikat sejarah atau bahkan sama dengan sejarah, betapapun dunia dalam karya sastra tidak selalu mengangkat peristiwa masa lalu. Tetapi mengingat karya sastra dan sejarah, keduanya bersumber dari peristiwa atau pengalaman masa lalu yang sudah terjadi, maka karya sastra dan sejarah menempatkan dirinya sebagai karya yang merekam peristiwa. Kemudian menjadi sebuah dokumen atau catatan tentang seseorang, bangunan, peristiwa, atau apapun yang berkaitan dengan masa lalu.

Lebih jauh Mahayana (2005:361) menjelaskan bahwa sebuah karya sastra adalah ciptaan pengarang yang tidak terlepas dari kreasi imajinatif, maka pandangan bahwa karya sastra sebagai dokumen realitas, mesti dimaknai sebagai realitas yang telah mengalami proses pengendapan di dalam pemikiran pengarangnya. Dalam hal ini, pengalaman pengarang yang telah melalui proses pengamatan, perenungan, penghayatan dan penilaian itu, kemudian dibaluri sedemikian rupa oleh kekuatan imajinasi. Hasilnya adalah refleksi realitas imajinatif. Masih menurut Mahayana (2005:362-363), secara subyektif, sastrawan dapat memaknai dan menafsirkan fakta atau peristiwa sejarah menurut kepentingannya. Ia juga dapat menyampaikan alternatif lain di balik peristiwa-peristiwa sejarah. Jadi, sastrawan bisa saja menjadikan fakta dan peristiwa sejarah sebagai latar belakang karya kreatifnya, tetapi ia juga dapat memanfaatkan fakta dan peristiwa sejarah untuk menyampaikan catatan kritisnya atau untuk mengungkapkan peristiwa yang mungkin terluput dari catatan sejarah. 
Dunia sastra merupakan tiruan (mimesis) dari dunia nyata sehingga dapat dikatakan peristiwa-peristiwa dalam dunia sastra merupakan refleksi dari dunia nyata. Oleh sebab itu, bisa saja karya sastra merupakan dokumen yang mencatat realitas masa lalu menurut pengamatan, pencermatan dan pemikiran subjektif pengarang. Dalam hal ini, sebagaimana dikatakan Junus (1981:72-75), pengertian karya sastra sebagai refleksi realitas, tidak sekadar melaporkan realitas itu sendiri, namun melaporkan realitas yang telah menjadi pemikiran pengarangnya.

Realitas kesejarahan dan realitas sosial politik dalam cerita menjadikan penelitian ini juga menggunakan pendekatan sosiologi sastra. Pendekatan sosiologi sastra adalah sebuah pendekatan sastra yang mengacu pada cara memahami dan menilai sastra yang mempertimbangkan segi-segi kemasyarakatan (sosial). Perkembangan sosiologi sastra sebenarnya merupakan perkembangan dari pendekatan mimetik yang memahami karya sastra dalam hubungannya dengan realitas dan aspek sosial kemasyarakatan.

Wellek dan Warren (dalam Budianta, 2001: 11) membagi sosiologi sastra sebagai berikut.

1) Sosiologi pengarang, profesi pengarang, dan istitusi sastra, masalah yang berkaitan di sini adalah dasar ekonomi produksi sastra, latar belakang sosial status pengarang, dan idiologi pengarang yang terlibat dari berbagai kegiatan pengarang di luar karya sastra;

2) Sosiologi karya sastra yang memasalahkan karya sastra itu sendiri yang menjadi pokok penelaahannya atau apa yang tersirat dalam karya sastra dan apa yang menjadi tujuannya; dan

3) Sosiologi sastra yang memasalahkan pembaca dan dampak sosial karya sastra, pengarang dipengaruhi dan mempengaruhi masyarakat; seni tidak hanya meniru kehidupan, tetapi juga membentuknya.
Klasifikasi Wellek dan Warren sejalan dengan klasifikasi Ian Watt (dalam Damono, 2010:3-6) yang membagi hubungan antara sastra dan masyarakat sebagai berikut. 1) Konteks sosial pengarang, dalam hal ini ada kaitannya dengan posisi sosial sastrawan dalam masyarakat, dan kaitannya dengan masyarakat pembaca termasuk juga faktor-faktor sosial yang dapat mempengaruhi karya sastranya; 2) Sastra sebagai cermin masyarakat, maksudnya seberapa jauh sastra dapat dianggap carmin keadaan masyarakat. Pengertian "cermin" dalam hal ini masih kabur, karena itu, banyak disalahtafsirkan dan disalahgunakan. Yang harus diperhatikan dalam klasifikasi sastra sebagai cermin masyarakat adalah (a) sastra mungkin tidak dapat dikatakan mencerminkan masyarakat pada waktu ditulis, sebab banyak ciri-ciri masyarakat ditampilkan dalam karya itu sudah tidak berlaku lagi pada waktu ia ditulis, (b) sifat "lain dari yang lain" seorang pengarang sering mempengaruhi pemilihan dan penampilan fakta-fakta sosial dalam karyanya, (c) genre sastra sering merupakan sikap sosial suatu kelompok tertentu, dan bukan sikap sosial seluruh mayarakat, (d) sastra yang berusaha untuk menampilkan keadaan masyarakat secermat-cermatnya mungkin saja tidak dapat dipercaya sebagai cermin masyarakat. Sebaliknya, sastra yang sama sekali tidak dimaksudkan untuk menggambarkan masyarakat mungkin masih dapat digunakan sebagai bahan untuk mendapatkan informasi tentang masyarakat tertentu. Dengan demikian, pandangan sosial pengarang diperhitungkan jika peneliti karya sastra sebagai cermin masyarakat; dan 3) Fungsi sosial sastra, maksudnya seberapa jauh nilai sastra berkaitan dengan nilai-nilai sosial.

Menurut Laurenson dan Swingewood (dalam Roemiati, 2016:31) terdapat tiga perspektif berkaitan dengan sosiologi sastra, yaitu: 1) penelitian yang memandang karya sastra sebagai dokumen sosial yang di dalamnya merupakan refleksi situasi pada saat sastra 
diciptakan; penelitian yang mengungkap sastra sebagai cermin situasi social penulisnya; dan 3) penelitian yang menangkap sastra sebagai manifestasi peristiwa sejarah dan keadaan sosial budaya. Dengan demikian penelitian ini menggunakan perspektif yang ketiga karena bertujuan ingin mengetahui aspek-aspek kesejarahan dan realitas sosial politik yang terdapat dalam novel Para Priyayi karya Umar Kayam.

Penelitian ini merupakan penelitian kualitatif dengan menggunakan metode deskriptif kualitatif. Metode kualitatif adalah metode yang paling cocok bagi fenomena sastra (Endraswara, 2011:5). Sesuai dengan pendapat Bogdan dan Taylor (dalam Moleong, 2010:4) penelitian kualitatif adalah prosedur penelitian yang menghasilkan data deskriptif berupa kata-kata tertulis atau lisan tentang orang-orang dan perilaku yang dapat diamati. Metode deskriptif adalah metode yang dilakukan dengan tidak menggunakan angka-angka, tetapi menggunakan penghayatan terhadap interaksi antar konsep yang sedang dikaji secara empiris (Semi, 2012:23). Selain itu, metode analisis konten juga digunakan untuk menelaah isi teks untuk mengetahui penggambaran karakter positif tokoh utama dalam novel. Analisis konten adalah strategi untuk menangkap pesan karya sastra (Endraswara, 2011: 161).

Pendekatan yang digunakan adalah pendekatan sosiologi sastra untuk mengetahui kandungan sosiopolitik yang terdapat dalam cerita.

Teknik studi pustaka dilakukan untuk mencari informasi dari buku-buku yang dianggap relevan dengan penelitian yang dilakukan. Buku tersebut dapat diperoleh dari perpustakaan atau koleksi pribadi.

Sumber data penelitian adalah novel Para Priyayi Sebuah Novel terbitan tahun 2008. Adapun data penelitian adalah teks-teks dalam cerita yang dapat berupa kata, kalimat atau paragraf yang mengandung unsur-unsur ke- sejarahan dan sosiopolitik yang terdapat dalam cerita.

\section{HASIL DAN PEMBAHASAN}

Novel Para Priyayi sesungguhnya banyak sekali memuat informasi kesejarahan yang terjadi di Indonesia. Hal itu disebabkan novel Para Priyayi memiliki latar waktu di tiga zaman, yaitu pada saat Indonesia masih di jajah oleh Belanda kemudian di jajah oleh Jepang sampai pada pasca kemerdekaan. Dengan demikian, Novel Para Priyayi ini sarat dengan refleksi kesejarahan terutama sejarah yang terjadi di Indonesia pada umumnya dan tanah Jawa pada khususnya.

\section{Refleksi Sejarah dalam Novel Para Priyayi}

\section{Zaman Penjajahan Belanda}

Pada mulanya di dalam masyarakat Jawa tradisional hanya mengenal dua kelompok masyarakat, yaitu masyarakat priyayi bangsawan dan wong cilik. Menurut Geertz (2016:30) priyayi, atau terutama sekali raja dianggap mempunyai kekuatan spiritual yang "mengalir ke luar dan ke bawah dari pancuran kerajaannya yang semakin menipis ketika merembes menembus tiap lapisan dalam birokrasi dan akhirnya mengalir lemah ke dalam massa petani." Oleh sebab itu, semakin jauh kediaman seseorang dari pusat kediaman para bangsawan semakin sedikit kekuatan spiritual raja yang dimilikinya dan semakin rendah kedudukannya. Kelompok wong cilik ini adalah petani, pedagang, dan pengrajin sedangkan yang termasuk kelompok priyayi adalah para bangsawan. Dalam kelompok yang terakhir ini tinggi rendah derajat seseorang ditentukan oleh jauh dekatnya hubungan kekerabatannya dengan raja sehingga pengertian priyayi secara etimologis berasal dari kata para yayi yang berarti para adik, maksudnya adik raja.

Apa yang dikemukakan itu merupakan merupakan struktur sosial tradisional Jawa. Dalam struktur itu orang-orang Jawa mempunyai kedudukan yang sudah tetap dan dapat 
menerima kedudukan itu sebagai sesuatu yang wajar dan benar. Orang yang berasal dari keturunan wong cilik akan menempatkan dirinya dalam kelompok wong cilik sedangkan yang berasal dari priyayi menempatkan diri dalam kelompok priyayi. Setiap orang mengetahui dan menerima batas-batas hak dan kewajibannya sesuai dengan kelompok yang di dalamnya ia termasuk.

Sejak pertengahan abad ke-17 Belanda masuk dan berkuasa di Jawa. Hubungan antara pemerintahan dengan rakyat dilaksanakan dengan sistem hubungan tidak langsung, yaitu hubungan mereka dilaksanakan melalui perantara kaum bangsawan yang menjadi penguasa tradisional Jawa. Oleh karena itu, meskipun kedatangan Belanda amat mengganggu kekuasaan para bangsawan, struktur sosial masyarakat jawa relatif tidak berubah. Belanda masih mempertahan kan sistem priyayi dan wong cilik seperti yang berlaku sebelumnya.

Abad ke-19 merupakan abad yang cukup mengguncangkan bagi struktur masyarakat Jawa. Kecenderungan pemerintah Belanda untuk meningkatkan efesiensi dalam birokrasi, untuk memberikan pelayanan kesehatan pada masyarakat pribumi, dan untuk membendung "ledakan Islam" menyebabkan munculnya kebutuhan akan tenaga terampil dalam berbagai bidang pekerjaan dan kebutuhan akan kelompok pribumi yang seideologi dengan mereka. Untuk memenuhi kebutuhan itu didirikanlah oleh pemerintah Belanda berbagai jenis sekolah gaya barat (modern). Pada tahun 1851 telah berdiri sekolah guru bantu (kweekschool) dan sekolah dokter Jawa. Kemudian Belanda mendirikan HIS (sekolah yang setingkat dengan sekolah dasar sekarang), MULO (setingkat dengan SMP sekarang), dan AMS (setingkat dengan SMA sekarang.

Pendirian-pendirian sekolah tersebut ternyata mendapat sambutan dari kelompok pribumi pada waktu itu, terutama dari kelompok priyayi (bangsawan) rendah dan wong cilik. Hal itu disebabkan peranan sekolah itu sendiri yang dapat meningkatkan status sosial dan ekonomi mereka. Posisi-posisi sosial yang dahulu dapat diraih hanya dengan satu criteria, yaitu keturunan atau geneologi (bangsawan/priyayi) dapat mereka raih dengan kriteria lain, yaitu kemampuan. Pendidikan merupakan alat mobilitas sosial atau peningkatan status sosial yang melenyapkan batas-batas sosial yang ada sebelumnya. Karena kemampuannnya, wong cilik dapat saja menduduki tempat terhormat dengan bekerja di lapangan-lapangan yang semula hanya diduduki oleh kaum bangsawan. Kelompok yang mengalami perubahan sosial itu sebagai akibat adanya pendidikan adalah kelompok yang disebut priyayi baru atau priyayi intelektual. Mereka ini merupakan kelompok yang memanfaatkan peluang-peluang yang ada dalam birokrasi atau lapangan kerja pemerintah sebagai alat peningkatan ekonomi dan status sosialnya. Oleh sebab itu struktur masyarakat Jawa yang tadinya hanya terdiri dari kelompok priyayi dan wong cilik berubah dengan adanya kelompok baru ini. Kelompok ini boleh dikatakan sebagai kelompok yang terletak di tengah-tengah antara dua golongan social tadi.

Novel Para Priyayi sebagian besar menceritakan kehidupan priyayi yang berasal dari kelompok wong cilik tersebut. Novel ini dimulai ketika Soedarsono pulang dari Madiun dengan mengantongi beslit sebagai guru bantu. Soedarsono merupakan anak petani yang merupakan menjadi salah satu perwakilan dari masyarakat Jawa yang memiliki keinginan kuat untuk dapat memasuki sekolah-sekolah Belanda. Besarnya animo masyarakat Jawa untuk memasuki sekolah-sekolah Belanda itu disebabkan besarnya peranan sekolah itu sendiri dalam meningkatkan status sosial serta ekonomi mereka di tengah-tengah masyarakat.

Setelah mempunyai anakpun Soedarsono yang kemudian berganti nama menjadi Sastrodarsono karena telah menjadi priyayi, menyekolahkan anak-anaknya di sekolahsekolah Belanda. Karena dari sekolah-sekolah 
itulah, anak-anak Sastrodarsono mempunyai kemungkinan lebih besar untuk dapat menduduki jabatan-jabatan di lingkungan birokrasi gupermen.

"Ketiga anaknya itu dimasukkan ke sekolah HIS, sekolah dasar untuk anak priyayi, karena sekolah itu diadakan untuk menyipakan priyayi-priyayi gupermen. Anakanak yang bersekolah di situ akan diajar bahasa Belanda, bahasa yang sangat penting buat mendapat kedudukan di kantor gupermen dan adapat meneruskan pelajaran ke sekolah menengah dan sekolah menengah atas priyayi, seperti MULO, AMS, atau sekolah-sekolah guru menengah seperti Normaal, Kweeksschool dan sebagainya (PP:52)

\section{Zaman Penjajahan Jepang}

Pada tahun 1942 Jepang datang ke Indonesia dan mengusir penjajah Belanda. Menurut Kartodirjo (1993:131) kedatangan Jepang ini sangat mempengaruhi kehidupan para priyayi. Bahkan boleh dikatakan priyayi yang merupakan satu kelompok birokrat colonial Belanda yang mempunyai gaji tetap dan pengemban serta penerus warisan budaya lama mengalami keruntuhan dan surut. Salah satu hal yang menyebabkan runtuhnya golongan priyayi ini adalah adanya kemerosotan kehidupan ekonomi karena inflasi yang terus menanjak sebagai akibat perang sedang penghasilan nominal sebagai pegawai negeri tidak berubah.

Keadaan tersebut tercermin pada kehidupan keluarga Noegroho, anak sastradarsono, yang merasa alangkah cepat perubahan yang ditimbulkan oleh pendudukan Jepang. Kehidupan terasa semakin susah. Dalam waktu setahun sudah mulai terasa bagaaimana ekonomi perang mulai menghimpit keluarga.

"Jumlah itu jauh dari cukup. Sebelum Jepang datang kami cenderung hidup agak mewah. Maklum gaji guru sekolah gupermen yang seratus sepuluh gulden itu memang lebih dari cukup unruk menyangga kehidupan kami. Istri saya yang senang dengan makanan cara Belanda, jadi agak terpukul dengan keadaan yang merosot itu" (PP:178-179).

Para priyayi sebagai kelompok yang secara historis dekat dengan Belanda dan bahkan menjadi alat atau pegawai dalam birokrasi pemerintahan Belanda tidak begitu dipercayai oleh Jepang. Oleh sebab itu dengan sendirinya mereka mengalami kemerosotan dalam status dan ekonominya. Pemerintahan Jepang kala itu bahkan menghapuskan atau melarang pelaksanaan kebiasaan berbahasa Belanda yang pada masa lalu merupakan hal yang sangat dibanggakan oleh priyayi.

Sebaliknya dari kehidupan priyayi yang mengalami penurunan status menurut Pradopo (1986:204) para pemuda desa dan kaum santri mendapatkan kesempatan untuk meningkatkan derajatnya dalam pandangan masyarakat tanpa harus melalui jalur pendidikan barat, melainkan melalui jalur kemiliteran. Hal itu disebabkan pada waktu itu Jepang memerlukan sokongan tenaga untuk militer dan keamanan sehingga pada masa Jepang ini berkembang lembaga-lembaga alat mobilitas sosial baru seperti Keibodan dan Peta.

Hal ini juga tercermin pada kehidupan Noegroho. Noegroho sebagai priyayi guru yang sedang mengalami penurunan status dan ekonomi tanpa diduga mendapat panggilan untuk ikut tentara Peta atau Pembela Tanah Air.

"Ia harus segera berangkat ke Bogor untuk menjalani latihan daan saringan sebelum nantinya ditempatkan di salah satu daidan-daidan atau batalyon-batalyon di Jawa. Sesampai di Bogor, ternyata yang mengalami latihan itu tidak hanya guruguru seperti saya, tetapi juga para pemuka masyarakat, pemuka agama, dan pemudapemuda. Pada waktu latihan selesai, saya mendapat pangkat chundacho atau komandan kompi dan kemudian ditempatkan di daidan Jebukan, Bantul" (PP: 179-180). 
Setelah Noegroho menjadi opsir Peta, dengan sendirinya status sosial dan ekonominya mulai membaik kembali. Hal itu terungkap dari pengalaman Noegroho sendiri.

"Ternyata hidup di daidan lumayan. Kami para opsir tidak tinggal di asrama yang bekas pabrik gula itu. Kami tinggal di bekas rumah-rumah para pegawai pabrik. Rumah-rumah itu cukup besar dan mewah. Dan menjadi opsir Peta, dibandingkan dengan para pegawai sipil seperti guru pada zaman Jepang itu sangat jauh lebih lumayan. Setidaknya pembagian bahan makanan kami boleh dikatakan lebih dari cukup" (PP: 188).

\section{Zaman Kemerdekaan}

Menurut Notosusanto (2009:129) pada tahun 1945 Jepang kalah dalam perang AsiaPasifik melawan tentara sekutu. Bangsa Indonesia yang mengetahui kekalahan Jepang itu segera mempersiapkan diri untuk memproklamasikan kemerdekaannya. Berdasarkan kesepakatan bersama, akhirnya pada tanggal 17 Agustus 1945 bangsa Indonesia memproklamasikan kemerdekaannya melalui pembacaan teks proklamasi oleh Presiden Soekarno. Karena situasi keamanan setelah proklamasi belum pulih benar, pemerintah Indonesia pada tanggal 23 Agustus 1945 membentuk BKR (Badan Keamanan Rakyat) yang berfungsi sebagai penjaga umum pada asing-masing daerah.

Situasi tersebut juga tercermin dalam novel Para Priyayi melalui pengalaman Noegroho sebagai opsir Peta yang menyatakan bahwa:

"Tahu-tahu Jepang telah kalah perang dan kami, Peta dibuabarkan dan dilucuti senjata kami. Untunglah juga segera sesudah kita memproklamasikan kemerdekaan, kita mulai memikirkan akan pembentukan Badan Keamanan Rakyat di Yogya. Saya segera bergabung dengan kawan-kawan bekas Peta, Heiho, dan polisi dan para pemuda untuk menyusun Badan Keamanan Rakyat di Yogya" (PP:189).
Pengambilalihan kekuasaan dari tangan Jepang, rakyat juga berusaha untuk memperoleh senjata-senjata dari tangan Jepang. Akan tetapi, Jepang tidak mau begitu saja menyerahkan senjata-senjatanya. Oleh sebab itu, terjadilah pertempuran antara pihak republik dengan Jepang.

"Dalam pertempuran yang sengit di Kotabaru, daerah elite Yogya, pertempuran ini kacau balau karena barisan kami tidak sepenuhnya terdiri dari bekas Peta, atau Heiho yang sudah mendapat pendidikan ilmu perang, justru yang banyak adalah para pemuda dan rakyat yang tidak punya pengalaman bertempur ikut bergabung ingin ikut menunjukkan bahwa mereka juga berani perang melawan Jepang. Kebanyakan pemuda yang masih sangat muda dan banyak pula pemuda dari kampung-kampung di kota yang beruntung selamat langsung ikut menyerbu masuk asrama Jepang di Kotabaru, dekat stadion Kridosono, mengobrak-abrik apa yang ada serta merampas serta membagibagi senjata" (PP:189-190).

\section{Zaman Revolusi}

Setelah Jepang menyerah kalah kepada pasukan sekutu, tentara Inggris mulai memasuki Indonesia. Akan tetapi, ternyata pasukan Inggris ini diboncengi oleh tentara-tentara Belanda. Rupanya Belanda berniat untuk menguasai Indonesia kembali. Oleh sebab itu, pecahlah pertempuran dimana-mana. Peristiwa ini juga tergambar dalam novel Para Priyayi melalui Nogroho yang telah menjadi tentara republik.

"Pengalaman berperang yang sesungguh-
nya saya rasakan waktu saya ikut ditugas-
kan pasukan membendung tentara Inggris
yang diboncengi Belanda yang sudah
sampai di Magelang. Kami menggempur
mereka dengan kekuatan senjata seadanya
dan ilmu strategi perang yang seadanya
juga. Kami pukul mereka dengan gabung-
an antara pengetahuan yang kami dapat
di asrama Peta dan akal sehat dan di atas 
semuanya dengan kenekadan, kekaranjingan yang disulut revolusi, kami terus mengejar musuh hingga Ambarawa dan akhirnya memaksa mereka kembali bertahan di Semarang" (PP:190).

Zaman revolusi yang terjadi di Indonesia pasca kemerdekaan digambarkan dalam novel sebagai kepanjangan penderitaan zaman Jepang. Bedanya, zaman Jepang adalah penderitaan orang karena di jajah sedangkan penderitaan zaman revolusi adalah penderitaan sebagai konsekuensi dari keinginan sebuah bangsa yang ingin merdeka.

\section{Pemberontakan PKI}

Pemberontakan PKI terhadap Negara Indonesia yang masih sangat muda terjadi dua kali, yaitu tahun 1948 di Madiun dan tahun 1965. Pemberontakan PKI ini merupakan wujud pengkhianatan yang tiada tara terhadap bangsa Indonesia. Hal itu disebabkan tatkala Indonesia sedang bergulat mati-matian melawan kolonialis Belanda, PKI secara licik menusuk dari belakang. Pemberontakan PKI yang pertama di Madiun yang di pimpin oleh seseorang yang bernama Muso. Hal itu tergambar dalam novel sebagai berikut.

"Hal yang kemudian mengkhawatirkan adalah perkembangan PKI dan pengaruhnya dalam tubuh tentara, terutama di Solo. Baik dari sumber penyelidik tentara maupun dari cerita-cerita Hardojo, semua menggambarkan Solo dalam keadaan panas. Culik-menculik dan penembakan gelap terjadi yang kemudian juga disertai dengan stelengan-stelengan pasukan yang tidak mau dirasionalisasi. Kemudian puncak dari itu semua adalah pemberontakan PKI di Madiun. Akhirnya pasukan-pasukan Siliwangi yang ditugaskan untuk menumpasd pemberontakan itu" (PP:192-192).

Pemberontakan PKI di Madiun ini akhirnya dapat di padamkan. Akan tetapi, ternyata bukan berarti PKI telah mati di Indonesia. Rupanya mereka tetap hidup. Sejak tahun 1950 mereka muncul kembali dan semakin membesar. Puncaknya adalah pemberontakan PKI tanggal 30 September 1965, suatu pemberontakan yang mengambil nyawa beribu-ribu orang. Hal ini terlihat melalui penuturan Harimurti, cucu dari Sastrodarsono, yang terlibat dengan Lekra yang menuturkan sebagai berikut.

"Saya mengetahui bahwa ekor dari gerak-
an pemberontakan itu telah mengambil
nyawa beribu-ribu, berpuluh ribu, mung-
kin beratus ribu orang. Alangkah mengeri-
kan dan menegakkan bulu roma. Bagai-
mana kekejaman itu bisa berkembang men-
jadi kekejaman yang lebih besar lagi bagai-
kan ombak yang menggulung sampai ke-
mana-mana" (PP:288).

\section{Refleksi Kehidupan Sosial Politik dalam Novel Para Priyayi}

Novel Para Priyayi sesungguhnya mengembil waktu penceritaan sekitar awal abad ke-20, yaitu masa bangkitnya kesadaran nasional di kalangan priyayi. Menurut Kartodirdjo (1993:1171) masalah kesadaran politik dikalangan priyayi pada umumnya tidaklah terlalu menonjol. Jelas bahwa hal itu kesemuanya timbul dari idiologi yang didasarkan atas status-quo. Ide status-quo itu secara wajar timbul dari lokasi sosio-historis priyayi sebagai tulang punggung dalam sistem birokrasi kolonial yang setia, tekun, dan rajin melaksanakan tugasnya hidup aman tenteram serta menikmati kesejahteraan dalam kedudukannya yang terhormat itu.

Suatu perubahan yang akan mencapai tingkat politik, menjadikan golongan priyayi bersifat konservatif. Hal itu tidak lain disebabkan karena golongan ini sebagai pegawai kolonial secara wajar membela status-quo sehingga perubahannya dianggap sebagai ancaman terhadap kedudukannya itu.

Sikap hidup tersebut tanpak sejelas-jelasnya dalam perlakuan politik priyayi dalam menghadapi gerakan-gerakan pembaharuan pada umumnya dan perubahan politik khusus- 
nya. Hal ini tercermin pada sikap para priyayi teman Sastrodarsono di dalam novel Para Priyayi ketika dikabarkan tentang perbuatan Martoatmodjo yang terlibat pergerakan karena membaca surat kabar Medan Priyayi, sebuah Koran terbiatan kaum pergerakan.

"We, lha, nak guru. Jangan mulai mainmaain api, lho, berbahaya. Saya tahu Medan Priyayi itu menarik. Tapi, kalau gupermen, sudah melarang itu terbit dan membuang Mas Tito, penerbit Koran itu, kita terus mau apa. Sudahlah jangan cari susah sekarang. Nak guru masih muda, hari depan masih jauh lagi bagus. Jangan hanya karena membaca Koran yang sudah tidak terbit kenaikan pangkatmu macet". Romo Jaksa, Romo Mantri Candu juga sama pendapatnya dengan Romo Dokter. Semua melarang saya untuk menyimpan Medan Priyayi, apalagi ikut-ikutan perkumpulan Mas Martoatmodjo membahas isi mingguan-mingguan pergerakan itu" (PP:58).

Walaupun demikian, kesadaran politik disebagian priyayi tetap ada. Saslah satunya Martoatmodjo dan juga Ndoro Seten Kedungsimo yang menganggap priyayi yang berani berpolitik pada waktu itu dan berusaha mengubah kehidupan bangsanya sebagai priyayi maju. Hal itu terungkap melalui pengakuan Ndoro Seten sebagai berikut.

"Sastro, kamu pikir saya tempo hari ngotot betul berusaha memasukkan kamu ke kursus bantu untuk apa? Juga kawankawanmu yang lain dari desa-desa di bawah kekuasaan saya, saya usahakan masuk dipendidikan ini dan itu? Semua itu usaha saya bersama pangreh praja maju lainnya untuk membangun barisan priyayi maju, bukan priyayi yang dikemudian hari kepingin jadi raja kecil yang sewenang-wenang terhadap wong cilik. Ini monyet-monyet seperti School Opziener dan mantri polisi dan entah telik-telik, spiun-spiun picisan yang mana lagi dengan upah beberapa gulden jadi tega melapor-laporkan bangsa sendiri, yang bikin rusak semua usaha kami" (PP:63).

Sastrodarsono sendiri sedikit banyak juga terlibat dengan politik dengan melakukan perlawanan berupa mendirikan sekolah "liar" atas saran seorang tokoh pergerakan. Sekolah liar tersebut didirikan Sastrodarsono dengan maksud mencetak generasi muda bangsa yang cerdas dan terdidik yang nantinya dapat diharapkan dapat memberikan sumbangsih kepada Indonesia.

Keterlibatan Sastrodarsono dalam peristiwa politik tidak hanya di zaman Belanda saja. Pada saat Jepang berkuasa di Indonesia, semua abdi kekuasaan harus melakukan saikere, yaitu membungkukkan badan ke arah utara untuk menghormati Tenno Heika, sang Dewa Matahari. Sastrodarsono pun tidak luput dari kewajiban tersebut. Akan tetapi, Sastrodarsono menolak untuk melakukan saikere. Penolakan Sastrodarsono tersebut dapat diartikan sebagai bentuk perlawanan terhadap kekuasaan yang baru, yaitu Jepang. Akibatnya, Sastrodarsono ditempeleng oleh Tuan Sato, symbol kekuasaan Jepang pada waktu itu.

"Tiba-tiba dengan secepat kilat tangan Tuan Sato melayang menempeleng kepala Ndoro Guru Kakung. Plak! Plak! Ndoro Guru Kakung geloyoran tubuhnya. Dengan cepat saya tangkap bersama Menir Soetardjo terus kami dudukan di kursi goyang. Sang priyayi tua pucat pasi, lesu, aair matanya berlelehan keluar. Beliau nangis seperti anak kecil" (PP:128-129).

Rasa ketersinggungan Sastrodarsono yang sangat besar itulah yang membuat dia menangis. Sastrodarsono adalah seorang priyayi yang terbiasa dihormati oleh masyarakat. Akhirnya rasa ketersinggungan Sastrodarsono tersebut dapat diatasi dengan cara mendengarkan tembang bait pertama lagu Pocung dari serta Wedhatama.

Pengalaman dengan kekuasaan yang kedua kalinya yang dialami oleh Sastrodarsono adalah dalam masa pergolakan fisik setelah 
Bung Karno memproklamasikan kemerdekaan. Kini yang dialaminya adalah teror dari anggota PKI Madiun yang bernama Martokebo. Martokebo seorang blantik kerbau tetangga hendak membersihkan kampung dari para pamong praja dan priyayi-priyayi lainnya. Hal itu disebabkan pamong praja dan priyayipriyayi dianggap sebagai kelas borjuis penindas rakyat yang harus dilenyapkan karena tidak sesuai dengan idiologi komunis yang meniadakan kelas-kelas sosial.

"Dengan semangat revolusioner Martokebo "menaruh ujung kelewang di dada bapak", priyayi Sastrodarsono. Martokebo yang biasa berbahasa kromo halus kini beralih kebahasa ngoko yang geram dan kasar. "Apa Darsono? Kowe tertawa? Iya, tertawa? Sang priyayi tua itu diam, "Keringat dingin mengucur di seluruh badan" (PP:178).

Untunglah situasi itu dapat diselesaikan dengan cara Ndoro Putri, menyapa Martokebo dengan bahasa Jawa Krama, bahasa Jawa tinggi yang secara unik membuat seluruh jiwa revulusioner Martokebo sirna. Penyapaan tersebut membuat Martokebo tidak mampu lagi menahan terus pedang itu tertempel di dada Sastrodarsono walaupun akhirnya dia memakan korban lain, yaitu Jaksa dan Haji Mansur.

Keadaan berikutnya yang bernuansa politis adalah ketika gestapu sudah dikalahkan, ketika bukan Dewan Revolusi, tetapi ABRI yang telah mengambuil alih kekuasaan dan mulai melakukan pembersihan terhadap semua anggota PKI dan ormas-ormasnya. Salah satu cucu Sastrodarsono yang bernama Hari yang terlibat Lekra akhirnya ditangkap oleh pihak yang berwajib. Mulanya, Hari berniat untuk melarikan diri, tetapi Hari dinasihatkan untuk: “.....sebaiknya kamu jangan lari. Nanti kita cari jalan yang sebaiknya agar kau bisa selamat" (PP:280). Hari akhirnya dijebloskan ke dalam penjara.

Penyelesaian terhadap kasus hari ini dilakukan dengan menggunakan koneksi pamannya sendiri, yaitu Pakde Noegroho yang telah menjadi seorang kolonel di Angkatan Darat. Noegroho dengan segala jaringan koneksi yang dimilikinya akhirnya berhasil mengeluarkan Hari dari penjara dan beraubah status menjadi tahanan rumah saja. Nogroho merasa bangga dengan perbuatannya itu dan berucap, "tidak ada yang lebih menyenangkan bagi seorang pakde daripada dapat menolong kemenakannya. Ini kewajiban trah, kewajiban keluarga besar..."(PP:285).

\section{PENUTUP}

Novel Para Priyayi karya Umar Kayam adalah sebuah novel yang sangat kaya dengan unsur-unsur sejarah yang dimilikinya. Selain itu, realitas sosial politik yang terkandung dalam novel tersebut dapat dikatakan merupakan cermin zamannya.

Unsur-unsur sejarah yang terdapat dalam novel Para Priyayi melingkupi zaman Belanda, Jepang, kemerdekaan, revolusi, dan adanya pemberontakan PKI di Indonesia.

Zaman Belanda melahirkan sebuah kelompok baru dalam struktur sosial masyarakat Jawa. Struktur sosial masyarakat Jawa tradisional pada mulanya hanya terbagi menjadi dua, yaitu priyayi dan wong cilik. Akibat kebijakan Belanda yang banyak mendirikan sekolah-sekolah karena sedang memerlukan akan tenaga terampil dalam berbagai bidang pekerjaan dan kebutuhan akan kelompok pribumi yang seideologi dengan mereka maka lahirlah kelompok priyayi baru di Jawa. Kelompok ini boleh dikatakan terletak di tengahtengah antara kelompok priyayi bangsawan dengan wong cilik dalam struktur masyarakat Jawa.

Zaman Jepang di lukiskan sebagai zaman yang susah buat para priyayi. Hal itu disebabkan Jepang tidak percaya dengan kelompok priyayi. Priyayi dianggap oleh Jepang sebagai kelompok loyalis Belanda yang dengan sendirinya tidak begitu diberikan ruang oleh pemerintahan Jepang pada waktu itu. 
Zaman kemerdekaan dikisahkan dalam novel merupakan zaman pembersihan terhadap kekuatan Jepang di Indonesia. Pertempuran untuk merebut senjata Jepang dilakukan oleh satuan BKR (Badan Keamanan Rakyat).

Zaman revolusi merupakan zaman pertempuran kembali dengan Belanda karena Belanda rupanya ingin berkuasa kembali di Indonesia dengan secara licik memboncengi tentara Inggris.

Pemberontakan PKI di Indonesia dilakukan dua kali, yaitu yang pertama di Madiun dan kedua geger gestapu pada tahun 1965. Pemberontakan PKI ini merupakan sebuah bentuk pengkhianatan yang tiada tara terhadap Negara Indonesia yang baru berdiri.

Realitas sosial politik dalam cerita terlihat melalui persentuhan dan kejadian yang menimpa para tokoh dengan kebijakan politik pada zamannya. Penggambaran tokoh yang bersentuhan dengan realitas politik terjadi di zaman Belanda, Jepang, kemerdekaan, dan pada saat pemberontakan PKI di Indonesia.

\section{DAFTAR PUSTAKA}

Ali, R.M. 2005. Pengantar Ilmu Sejarah Indonesia. Yogyakarta: LkiS

Damono, Sapardi Djoko. 2010. Sosiologi Sastra: Pengantar Ringkas). Ciputat: Editum.

Endraswara, Suwardi.2011. Metodologi Penelitian Sastra: Epistemologi, Model, Teori, dan Aplikasi. Yogyakarta: Pustaka Widyatama.

Geertz, Clifford. 2016. Abangan, Santri, Priyayi dalam Masyarakat Jawa. Jakarta: Pustaka Jaya.

Junus, Umar. 1981. Dasar-Dasar Interpretasi Sajak. Kuala Lumpur: Heinemann Asia. 1984. Kaba dan Sistem Sosial Minangkabau Suatu Problema Sosiologi Sastra. Jakarta: PN Balai Pustaka.

Kartodirdjo, Sartono, A. Sadewo, Suhardjo Hatmo Suprobo. 1993. Perkembangan Peradaban Priyayi. Yogyakarta: Gajah Mada Universty Press.
Kayam, Umar. 2008. Para Priyayi Sebuah Novel. Jakarta: Pustaka Utama Grafiti.

Khakim, Nurfahrul Lukmanul. 2016. Telaah Penulisan Karya sastra Sejarah sebagai Refleksi Sumber Pembelajaran Sejarah. Jurnal Sejarah dan Budaya 10 (1): 15-30. Malang: Universitas Negeri Malang.

Kuntowijoyo. 2008. Penjelasan Sejarah. Yogyakarta: Tiara Wacana

Mahayana, Maman S. 2005. Jawaban Sastra Indonesia. Jakarta: Bening.

Moleong, Lexy. J. 2010. Metode Penelitian Kualitatif. Bandung: Remaja Rosda Karya.

Notosusanto, Nugroho, dkk. 2009. Sejarah Nasional Indonesia (Jilid 3). Jakarta: Balai Pustaka

Pradopo, Sri Widati dkk. 1986. Pengarang Wanita dalam Sastra Jawa Modern. Jakarta: Pusat Pembinaan dan Pengembangan Bahasa.

Roesmiati, Dian. 2016. Refleksi Sejarah dan Nilai Sosial-Politik dalam Novel Titik Balik Kesunyian Karya Ilham Zoebazary. Jurnal Bebasan 3 (1): 28-40. Banten: Kantor Bahasa Banten.

Semi. M. Atar. 2012. Metode Penelitian Sastra. Bandung: Angkasa Jaya.

Teeuw, A. 2003. Sastra dan Ilmu Sastra. Jakarta: PT Dunia Pustaka Jaya

Wellek, R. \& Waren, A. (2001). Teori kesusastraan. (Budianta, M., penerjemah). Jakarta: Gramedia. (karya asli terbit pertama tahun 1977). 